\title{
Extraction Socket Preservation Using Porcine-Derived Collagen Membrane Alone or Associated with Porcine-Derived Bone. Clinical Results of Randomized Controlled Study
}

\author{
Renzo Guarnieri ${ }^{1}$, Luigi Stefanelli ${ }^{1}$, Francesca De Angelis ${ }^{1}$, Francesca Mencio ${ }^{1}$, Giorgio Pompa ${ }^{1}$, \\ Stefano Di Carlo ${ }^{1}$ \\ ${ }^{1}$ Department of Dental and Maxillofacial Sciences, School of Dentistry, University La Sapienza, Rome, Italy.
}

Corresponding Author:

Renzo Guarnieri

Via L. Cattarin, 3D, 31100 Treviso TV

Italy

E-mail: renzoguarnieri@gmail.com

\begin{abstract}
Objectives: The aim of present randomized controlled clinical trial was to clinically evaluate hard tissue changes after extraction socket preservation procedures compared to natural spontaneous healing.

Material and Methods: Thirty patients were enrolled in the present study and underwent single-tooth extraction in the premolar/molar areas. Ten sites were grafted with porcine-derived bone covered by collagen membrane, 10 covered by porcinederived collagen membrane alone, and 10 underwent natural spontaneous healing. Vertical and horizontal bone changes after 3-month were evaluated at implant placement.

Results: The vertical and horizontal bone changes at the extraction sockets treated with collagen membrane alone (vertical: -0.55 [SD 0.11] mm, and horizontal: -1.21 [SD 0.69] $\mathrm{mm}$ ) and collagen membrane plus porcine-derived bone (vertical: -0.37 [SD 0.7$] \mathrm{mm}$, and horizontal: -0.91 [SD 0.53$] \mathrm{mm})$ were found significantly lower $(\mathrm{P}<0.001)$, when compared to non-grafted sockets (vertical: -2.09 [SD 0.19] mm, and horizontal: -3.96 [SD 0.87] mm).

In type 1 extraction sockets, in premolar sites, and in presence of vestibular bone thicknesses $\geq 1.5 \mathrm{~mm}$, the use of collagen membrane alone revealed similar outcomes to those with additional graft material.

Conclusions: At the re-entry surgery, extraction sockets grafted with porcine-derived bone and covered by collagen membrane, and extraction sockets covered by porcine-derived collagen membrane alone, showed significantly lower vertical and horizontal bone changes, compared to extraction sockets sites underwent natural spontaneous healing. However, a complete prevention of remodelling is not achievable, irrespective of the technique used.
\end{abstract}

Keywords: alveolar bone loss; alveolar ridge augmentation; bone resorption; bone substitutes; dental implants; tooth socket.

\author{
Accepted for publication: 28 September 2017 \\ To cite this article: \\ Guarnieri R, Stefanelli L, De Angelis F, Mencio F, Pompa G, Di Carlo S. \\ Extraction Socket Preservation Using Porcine-Derived Collagen Membrane Alone or Associated with Porcine-Derived Bone. \\ Clinical Results of Randomized Controlled Study \\ J Oral Maxillofac Res 2017;8(3):e5 \\ URL: http://www.ejomr.org/JOMR/archives/2017/3 /e5/v8n3e5.pdf \\ doi: $\underline{10.5037 / j o m r .2017 .8305}$
}




\section{INTRODUCTION}

After tooth extraction, the spontaneous alveolar bone healing is characterized by a remodelling and reabsorption process [1-7], which occurs rapidly and can determine in the first 6 months the loss of about $40 \%$ of the height and $60 \%$ of the width of the alveolar bone [ $\underline{8-10}]$. These changes could compromise the aesthetic outcome of final restorations, either with implant placement or with traditional prosthetic rehabilitations. Because the best period to preserve the alveolar ridge is at the time of extraction $[6,10,11]$, extraction socket preservation (ESP) procedure has been proposed as a mean of counteracting post-extraction volume loss [12-14]. Non-absorbable and absorbable membranes with or without graft materials, have been used for ESP to maintain the dimensions of the alveolar ridge following extraction [15]. The use of membrane alone in ESP has been translated by the conception of guided bone regeneration (GBR) [16], to exclude soft tissues from filling the osseous defect, and thus allowing the cells with osteogenic potential to colonize the wound [17-20]. ESP with GBR resulted in statistically significant less resorption in ridge width and height compared to unassisted socket healing, regardless of the type of membrane (absorbable/non-absorbable) [19,20]. A recent meta-analysis by Vittorini Orgeas et al. [21] indicated that the use of barrier membranes alone might improve normal wound healing in extraction sites. However, due to the lack of stiffness and space making properties of absorbable membranes, their ability to maintain alveolar ridge morphology is still questionable. Graft materials provide a mechanical support to absorbable membranes during the healing phase. Moreover, based on their osteogenic, osteoconductive, or osteoinductive properties [22], graft materials act as stimulants or scaffolds for bone growth. Several grafting materials have already been investigated alone or with membranes for ESP, such as autogenous bone, allografts, xenografts, and alloplasts; their clinical advantages in ESP are largely supported by the available literature [23-28]. Among the xenogenic bone grafts, porcine-derived bone has been recently evaluated for bone regeneration [29-31]. Furthermore, several studies suggested that hard tissue changes after tooth extraction could be limited by ESP techniques performed with adsorbable membranes associated with porcine-derived bone $[\underline{32}, \underline{33}]$.

The aim of this randomized controlled study was to compare and evaluate the clinical outcomes of three techniques: (1) ESP with a collagen membrane alone,
(2) ESP with a collagen membrane and porcinederived bone, and (3) natural spontaneous healing.

The two ESP techniques were also compared to each other to determine their respective efficacy in preserving the alveolar ridge dimensions following tooth extraction. This study reported preliminary clinical and radiographic findings at 3 months after ridge preservation.

\section{MATERIAL AND METHODS}

Thirty patients, requiring extraction of a single premolar or molar tooth, who were interested in receiving a dental implant, were enrolled in the study between September 2016 and December 2016.

Criteria for inclusion in the study were:

- Age $\geq 18$ years;

- Good general health, no pregnancy, no uncontrolled metabolic disorders;

- Adequate restorative space for implant-retained restoration;

- At least $10 \mathrm{~mm}$ alveolar bone height without impingement on the maxillary sinus or mandibular canal.

Exclusion criteria were:

- History of systemic diseases that contraindicate oral surgery;

- Long-term non-steroidal anti-inflammatory drug therapy;

- Oral bisphosphonate therapy;

- Pregnancy or lactation;

- Unwillingness to return for the follow-up examinations;

- Cigarette consumption > 10 per day;

- Absence of vestibular or lingual socket wall, or $>$ $50 \%$ missing vestibular/lingual socket wall.

All patients were informed about the evidence-based, positive outcome of ESP technique followed by implant placement, and the experimental approach. Each patient signed a free informed consent form after he/she has received detailed information about the study. Treatments were performed according to the principles outlined in the Declaration of Helsinki on experimentation involving human subject, and approved by the ethical committee (protocol no. 4597). Patients were divided into three groups of 10 subjects each:

1. Group S: extraction sockets with spontaneous healing.

2. Group M: extraction sockets covered with collagen membrane alone (Mem-Lok Pliable ${ }^{\circledR}$, BioHorizons, Birmingham, Al, USA).

3. Group GM: extraction sockets grafted 
with porcine-derived bone (MinerOss XP, BioHorizons, Birmingham, Al, USA), and covered with collagen membrane (Mem-Lok Pliable $^{\circledR}$, BioHorizons, Birmingham, Al, USA).

Mem-Lok Pliable ${ }^{\circledR}$ is a porcine-derived resorbable collagen-based membrane with an estimated resorption time of 12 to 16 weeks. Miner-Oss $\mathrm{XP}^{\circledR}$ is a highly porous anorganic porcine-derived bone mineral matrix with a particle size between 600 and $1000 \mu \mathrm{m}$. The allocation in S, M, and GM groups was randomly assigned to each patient by computer-generated random number table. The randomization codes were stored in password-protected portable computers and enclosed in sequentially numbered, identical, opaque, sealed envelopes. The envelopes were opened in numerical order after tooth extraction. A third operator not involved in enrolment or treatment of patients performed data collection.

The extraction socket evaluation was made according to the classification suggested by Juodzbalys et al. [34] (Table 1), i.e. socket type 1: adequate extraction socket; socket type 2: compromised extraction socket; socket type 3: deficient extraction socket.

\section{Surgical procedures}

All patients were prescribed prophylactic antibiotic therapy with $2 \mathrm{~g}$ of amoxicillin (or clindamycin 600 $\mathrm{mg}$ if allergic to penicillins) $1 \mathrm{~h}$ before the extraction procedure and continued postoperatively with $1 \mathrm{~g}$ of amoxicillin (or $300 \mathrm{mg}$ clindamycin) twice a day for 5 days. In addition, all patients rinsed for $1 \mathrm{~min}$ with chlorhexidine mouthwash $0.2 \%$ prior to the surgery (and twice a day for the following 3 weeks). Following local anaesthesia with 2\% lidocaine with adrenaline 1:50,000, the identified tooth was extracted in a minimally traumatic manner with periotomes and without raising a full thickness flap. If necessary, the tooth was sectioned.

After tooth extraction, the following clinical measurements were taken:

- Vestibular bone thickness (VBT), was measured with a surgical caliper $2 \mathrm{~mm}$ below the residual alveolar bone margin to the nearest $0.5 \mathrm{~mm}$, and dichotomized in two groups: (a) $<1.5 \mathrm{~mm}$ and (b) $\geq 1.5 \mathrm{~mm}$.

- Ridge width (RW) was measured at the midfacial level of the buccal bone plate using a surgical caliper $2 \mathrm{~mm}$ from the crest of the ridge to the nearest $0.5 \mathrm{~mm}$. If the vestibular or the lingual socket wall was missing, or a vestibular dehiscence greater than $50 \%$ of the length of the vestibular/lingual socket wall was present, the socket was not included in the study.

The heights of the vestibular and lingual crest (HVC-HLC) were measured by using a periodontal probe to connect the midfacial CEJs of the adjacent teeth, then measuring the vertical distance from that reference line to the crest of bone on the midfacial and midlingual sides. All measurements were performed by a single examiner (RG).

In the GM group, following preparation of interdental papilla with a pouch procedure, the extraction sockets were grafted up to the buccal and palatal alveolar bone walls and, subsequently, a collagen membrane was gently pushed under the interdental papilla with the use of periotomes. The collagen membrane was used to cover the fresh extraction socket entrance. A 4.0 or 5.0 monofilament suture (PTFE, Omnia SpA, Fidenza, Italy) was used to stabilize the membrane and prevent loss of graft particles. The collagen membrane was left exposed.

In the $M$ group, following preparation of interdental papilla with the same described procedure,

Table 1. Extraction socket classification [34]

\begin{tabular}{l|c|c|c}
\hline \multicolumn{1}{c}{ Parameters } & Type 1 & Type 2 & Type 3 \\
\cline { 2 - 4 } & All adequate & At least one compromised & At least one deficient \\
\hline Soft tissue contour variations & No & $<2 \mathrm{~mm}$ & $\geq 2 \mathrm{~mm}$ \\
\hline Vertical soft tissue deficiency & No & From 1 to $2 \mathrm{~mm}$ & $<1 \mathrm{~mm}$ \\
\hline Keratinized gingiva width & $>2 \mathrm{~mm}$ & From 1 to $2 \mathrm{~mm}$ & No papilla \\
\hline $\begin{array}{l}\text { Mesial and distal papilla } \\
\text { Gingival tissue biotype }\end{array}$ & $\begin{array}{c}\text { Hyperplastic/fills the } \\
\text { entire proximal space }\end{array}$ & $\begin{array}{c}\text { Lower of the normal contact point/ } \\
\text { less of half of normal papilla height }\end{array}$ & Hard: $\geq 2 \mathrm{~mm}$ \\
\hline $\begin{array}{l}\text { Soft tissue: color, consistence, } \\
\text { contour }\end{array}$ & Phick: $<2 \mathrm{~mm}$ & Moderate: from 1 to $2 \mathrm{~mm}$ & firm and smooth \\
\hline $\begin{array}{l}\text { Facial bone thickness } \\
\text { on the mid-buccal side }\end{array}$ & $\begin{array}{c}\text { Slightly red and a soft, spongy, } \\
\text { and uneven contour }\end{array}$ & $\begin{array}{c}\text { Red/bluish or red with a soft edematous } \\
\text { and boggy or craterlike appearance }\end{array}$ \\
\hline $\begin{array}{l}\text { Vestibular bone lesion } \\
\text { Palatal/lingual bone lesion }\end{array}$ & No $2 \mathrm{~mm}$ & From 1 to $2 \mathrm{~mm}$ & $\leq 1 \mathrm{~mm}$ \\
\hline
\end{tabular}




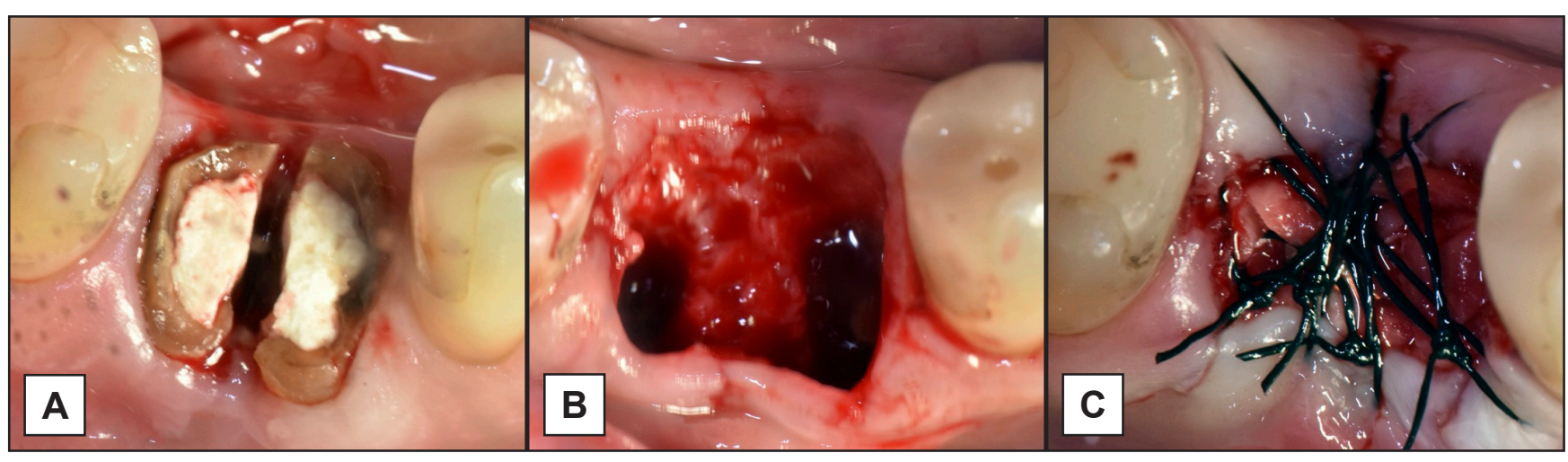

Figure 1. Example of extraction socket preservation technique. $\mathrm{A}=$ first molar roots separation; $\mathrm{B}=$ empty extraction socket; $\mathrm{C}=$ collagen membrane pushed under the interdental papilla and stabilized with monofilment suture.

a collagen membrane alone was gently pushed under the interdental papilla with the use of periotomes, and a 4.0 or 5.0 monofilament suture was used to stabilize the membrane.

In the S group, following tooth extraction, a 4.0 or 5.0 monofilament suture was used to stabilize the blood clot. Postoperative instructions were given and all patients were prescribed ibuprofen $600 \mathrm{mg}$ tablets. Subjects returned approximately 3 months after the extraction for a radiographic examination to evaluate the dimensions of the alveolus prior to implant placement. At the time of implant placement, 20 to 24 weeks post-extraction, minimal buccal and lingual flaps were reflected and ridge width, buccal and lingual heights were measured as previously described. In Figure 1 the surgical technique is showed.

\section{Statistical analysis}

Public domain online software (Raosoft, http:// www.raosoft.com/samplesize.html) was used to calculate the minimal number necessary for statistical evaluation. For the pooled data set as well as for each treatment group, the sample distributions of all variables were described univariately by showing means standard deviations (M [SD]), and medians. For each variable, a Kruskal-Wallis non-parametric one-way analysis of variance was performed, each at a level of 0.05. Each non-parametric ANOVA was followed by two-sided Wilcoxon's rank sum tests for pairwise comparisons including Bonferroni correction. The analysis was performed using $\mathrm{R}$ version 2.13.0 (R Development Core Team 2010).

\section{RESULTS}

Thirty patients were screened for this study. One of the subjects did not have enough ridge width for a correct implant placement upon re-entry, and only clinical measurements were made for that subject. Four patients exited due to discovery of a vestibular dehiscence greater than $50 \%$ of the length of the vestibular socket wall at the time of extraction, needing a mucoperiosteal flap. A total of 26 patients (14 males and 12 females with an average age of 46.7, ranging from 20 to 63 years) were allocated to the study groups of the trial. Patients' demographic data are reported in Table 2. At the end of the survey, 26 dental implants (Laser-Lok Tapered, BioHorizons, Birmingham, Al, USA) were placed.

Regression analysis suggested that, when the spontaneous healing group was the reference category, mean values of HVC, HLC and RW were significantly affected by the ridge preservation procedure employed (Table 3). Data analysis showed that tooth site could affect values of HVC, HLC and RW. In premolar sites, no statistical difference was found when the extraction socket was treated with collagen membrane alone or with collagen membrane associated with graft material. On the contrary, in molar sites the mean HVC, HLC, and RW values were significantly higher when the extraction socket was grafted with porcinederived bone associated with the collagen membrane (Table 3).

Table 2. Demographic data and dependent variables reported for the three experimental groups

\begin{tabular}{l|c|c|c}
\hline & \multicolumn{3}{|c}{ Group } \\
\hline $\begin{array}{l}\text { Demographics and dependent } \\
\text { variables }\end{array}$ & S & M & GM \\
\hline Patient (n) & 9 & 9 & 8 \\
\hline Age (years) & $21-56$ & $19-60$ & $20-63$ \\
\hline Sex (male/female) & $5 / 4$ & $3 / 6$ & $6 / 2$ \\
\hline Premolar/molar & $4 / 5$ & $6 / 3$ & $4 / 4$ \\
\hline Smoking habit (yes/no) & $2 / 7$ & $3 / 6$ & $3 / 5$ \\
\hline
\end{tabular}

$\mathrm{n}=$ number; $\mathrm{S}=$ spontaneous healing; $\mathrm{M}$ = porcine-derived collagen membrane alone; $\mathrm{GM}$ = porcine-derived graft material associated with collagen membrane. 
Table 3. Hard tissue changes for the three experimental groups according to the total sites and premolar and molar sites

\begin{tabular}{|c|c|c|c|c|c|c|}
\hline \multirow{2}{*}{ Variable } & S group & M group & GM group & S vs. $M$ & S vs. GM & M vs. GM \\
\hline & \multicolumn{3}{|c|}{ Mean (SD) in mm } & \multicolumn{3}{|c|}{ P-value } \\
\hline \multicolumn{7}{|l|}{ Total } \\
\hline$\Delta \mathrm{HVC}$ & $-2.13(0.18)$ & $-0.58(0.12)$ & $-0.31(0.05)$ & $<0.0001^{\mathrm{a}}$ & $<0.0001^{\mathrm{a}}$ & $0.0117^{\mathrm{b}}$ \\
\hline$\Delta \mathrm{HLC}$ & $-2.06(0.2)$ & $-0.52(0.11)$ & $-0.43(0.08)$ & $<0.0001^{\mathrm{a}}$ & $<0.0001^{\mathrm{a}}$ & $0.201^{\mathrm{b}}$ \\
\hline$\Delta \mathrm{RW}$ & $-3.96(0.87)$ & $-1.21(0.69)$ & $-0.91(0.53)$ & $<0.0001^{\mathrm{a}}$ & $<0.0001^{\mathrm{a}}$ & $0.0342^{\mathrm{b}}$ \\
\hline \multicolumn{7}{|l|}{ Premolar } \\
\hline$\Delta \mathrm{HVC}$ & $-2.07(0.6)$ & $-0.67(1.12)$ & $-0.69(0.79)$ & $<0.0001^{\mathrm{a}}$ & $<0.0001^{\mathrm{a}}$ & $0.2588^{\mathrm{b}}$ \\
\hline$\Delta \mathrm{HLC}$ & $-2.34(0.76)$ & $-0.58(1.40)$ & $-0.52(0.06)$ & $<0.0001^{\mathrm{a}}$ & $<0.0001^{\mathrm{a}}$ & $0.2439^{\mathrm{b}}$ \\
\hline$\Delta \mathrm{RW}$ & $-3.51(0,39)$ & $-0.58(1.97)$ & $-0.47(1.13)$ & $<0.0001^{\mathrm{a}}$ & $<0.0001^{\mathrm{a}}$ & $0.0251^{\mathrm{b}}$ \\
\hline \multicolumn{7}{|l|}{ Molar } \\
\hline$\Delta \mathrm{HVC}$ & $-2.16(0.03)$ & $-1.16(0.08)$ & $-0.67(0.07)$ & $<0.0001^{\mathrm{a}}$ & $<0.0001^{\mathrm{a}}$ & $<0.0001^{\mathrm{a}}$ \\
\hline$\Delta \mathrm{HLC}$ & $-2.09(0.73)$ & $-1.24(0.48)$ & $-0.59(0.26)$ & $<0.0001^{\mathrm{a}}$ & $<0.0001^{\mathrm{a}}$ & $<0.0001^{\mathrm{a}}$ \\
\hline$\Delta \mathrm{RW}$ & $-4.27(0.29)$ & $-1.21(0.81)$ & $-0.75(0.44)$ & $<0.0001^{\mathrm{a}}$ & $<0.0001^{\mathrm{a}}$ & $<0.0001^{\mathrm{a}}$ \\
\hline
\end{tabular}

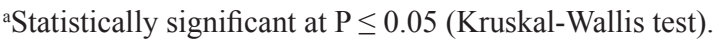

${ }^{\mathrm{b}}$ Statistically significant at $\mathrm{P}>0.05$ (Kruskal-Wallis test).

$\mathrm{SD}=$ standard deviation; $\Delta \mathrm{RW}=$ changes in ridge width, $\Delta \mathrm{HVC}=$ changes in height of the vestibular crest, $\Delta \mathrm{HLC}=$ changes in height of the lingual crest; $\mathrm{S}=$ spontaneous healing; $\mathrm{M}$ = porcine-derived collagen membrane alone; $\mathrm{GM}=$ porcine-derived graft material associated with collagen membrane.

In addition, results suggested that the vestibular bone thickness (VBT $<1.5 \mathrm{~mm}$ and $\mathrm{VBT} \geq 1.5 \mathrm{~mm}$ ) and post-extraction socket morphology (socket type 1, 2 and 3), could affect values of HBC, HLC and $\mathrm{RW}$. Indeed, in the presence of $\mathrm{WBT} \geq 1.5 \mathrm{~mm}$, no statistical difference was found between the group treated with collagen membrane alone, compared to the group treated with collagen membrane and porcine-derived bone. On the contrary, a statistically significant lower value of $\mathrm{HBC}, \mathrm{HLC}$, and RW was found at the re-entry surgery in presence of VBT $<1.5 \mathrm{~mm}$ in the group treated with collagen membrane alone, compared to group treated with collagen membrane and porcine-derived bone (Table 4). Extraction sockets type 1 showed no statistical difference in $\mathrm{HBC}$, HLC, and RW mean value when treated with membrane alone or with membrane and porcine-derived bone.
No statistical difference was found at the re-entry surgery in $\mathrm{HBC}, \mathrm{HLC}$, and RW mean values, when extraction sockets type 2 were treated with the two techniques, but statistically significant higher values of HBC, HLC, and RW were found in extraction sockets type 3 treated with membrane and porcine-derived bone, compared to those treated with collagen membrane alone (Table 5).

\section{DISCUSSION}

This randomized control trial was performed to compare the effect of two techniques (collagen membrane alone and collagen membrane plus porcine-derived bone) for ESP procedures with natural spontaneous healing on hard tissue levels.

Table 4. Hard tissue changes for the three experimental groups according to vestibular bone thickness (VBT)

\begin{tabular}{l|c|c|c|c|c|c}
\hline \multirow{2}{*}{ Variable } & S group & M group & GM group & S vs. M & S vs. GM & M vs. GM \\
\cline { 2 - 7 } & \multicolumn{7}{c}{ Mean (SD) in mm } & \multicolumn{3}{c}{ P-value } \\
\hline VBT $<\mathbf{1 . 5} \mathbf{~ m m}$ \\
\hline$\Delta$ HVC & $-2.14(0.08)$ & $-1.27(0.64)$ & $-1.21(0.26)$ & $<0.0001^{\mathrm{a}}$ & $<0.0001^{\mathrm{a}}$ & $<0.0001^{\mathrm{a}}$ \\
\hline$\Delta \mathrm{RW}$ & $-4.14(0.39)$ & $-1.24(0.37)$ & $-1.18(0.52)$ & $<0.0001^{\mathrm{a}}$ & $<0.0001^{\mathrm{a}}$ & $<0.0001^{\mathrm{a}}$ \\
\hline VBT $\geq \mathbf{1 . 5} \mathbf{~ m m}$ \\
\hline$\Delta \mathrm{HVC}$ & $-2.08(0.71)$ & $-0.42(0.64)$ & $-0.39(0.26)$ & $<0.0001^{\mathrm{a}}$ & $<0.0001^{\mathrm{a}}$ & $0.0578^{\mathrm{b}}$ \\
\hline$\Delta \mathrm{RW}$ & $-3.12(0.58)$ & $-0.72(0.36)$ & $-0.85(0.19)$ & $<0.0001^{\mathrm{a}}$ & $<0.0001^{\mathrm{a}}$ & $0.0593^{\mathrm{b}}$ \\
\hline
\end{tabular}

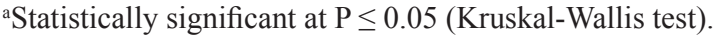

${ }^{b}$ Statistically significant at $\mathrm{P}>0.05$ (Kruskal-Wallis test).

$\mathrm{SD}=$ standard deviation; $\Delta \mathrm{RW}=$ changes in ridge width, $\Delta \mathrm{HVC}=$ changes in height of the vestibular crest; $\mathrm{S}=$ spontaneous healing; $\mathrm{M}=$ porcine-derived collagen membrane alone; $\mathrm{GM}$ = porcine-derived graft material associated with collagen membrane. 
Table 5. Hard tissue changes for the three experimental groups according to socket type

\begin{tabular}{l|c|c|c|c|c|c}
\hline \multirow{2}{*}{ Variable } & S group & M group & GM group & S vs. M & S vs. GM & M vs. GM \\
\cline { 2 - 7 } & \multicolumn{7}{c}{ Pean (SD) in mm } & \multicolumn{3}{c}{} \\
\hline Socket type 1 1 \\
\hline$\Delta$ HVC & $-1.08(0.71)$ & $-0.52(0.64)$ & $-0.49(0.26)$ & $<0.0001^{\mathrm{a}}$ & $<0.0001^{\mathrm{a}}$ & $0.0561^{\mathrm{b}}$ \\
\hline$\Delta$ HLC & $-0.92(0.48)$ & $-0.43(0.28)$ & $-0.41(0.59)$ & $<0.0001^{\mathrm{a}}$ & $<0.0001^{\mathrm{a}}$ & $0.0542^{\mathrm{b}}$ \\
\hline$\Delta$ RW & $-2.41(0.58)$ & $-0.31(0.35)$ & $-0.27(0.47)$ & $<0.0001^{\mathrm{a}}$ & $<0.0001^{\mathrm{a}}$ & $0.0748^{\mathrm{b}}$ \\
\hline Socket type 2 \\
\hline$\Delta$ HVC & $-1.56(0.39)$ & $-0.69(0.27)$ & $-0.42(0.73)$ & $<0.0001^{\mathrm{a}}$ & $<0.0001^{\mathrm{a}}$ & $<0.0001^{\mathrm{a}}$ \\
\hline$\Delta$ HLC & $-1.67(0.72)$ & $-0.52(0.69)$ & $-0.37(0.81)$ & $<0.0001^{\mathrm{a}}$ & $<0.0001^{\mathrm{a}}$ & $<0.0001^{\mathrm{a}}$ \\
\hline$\Delta$ RW & $-2.97(0.61)$ & $-1.16(0.25)$ & $-0.88(0.53)$ & $<0.0001^{\mathrm{a}}$ & $<0.0001^{\mathrm{a}}$ & $<0.0001^{\mathrm{a}}$ \\
\hline Socket type 3 & $-3.08(0.71)$ & $-2.51(0.19)$ & $-1.36(0.27)$ & $0.0179^{\mathrm{b}}$ & $<0.0001^{\mathrm{a}}$ & $<0.0001^{\mathrm{a}}$ \\
\hline$\Delta$ HVC & $-2.92(0.48)$ & $-2.39(0.78)$ & $-1.18(0.51)$ & $0.0124^{\mathrm{b}}$ & $<0.0001^{\mathrm{a}}$ & $<0.0001^{\mathrm{a}}$ \\
\hline$\Delta$ HLC & $-4.41(0.58)$ & $-3.94(0.26)$ & $-2.73(0.54)$ & $0.0209^{\mathrm{b}}$ & $<0.0001^{\mathrm{a}}$ & $<0.0001^{\mathrm{a}}$ \\
\hline$\Delta$ RW &
\end{tabular}

a Statistically significant at $\mathrm{P} \leq 0.05$ (Kruskal-Wallis test).

${ }^{\mathrm{b} S t a t i s t i c a l l y ~ s i g n i f i c a n t ~ a t ~} \mathrm{P}>0.05$ (Kruskal-Wallis test).

$\mathrm{SD}=$ standard deviation; $\Delta \mathrm{RW}=$ changes in ridge width, $\Delta \mathrm{HVC}=$ changes in height of the vestibular crest, $\Delta \mathrm{HLC}=$ changes in height of the lingual crest; $\mathrm{S}$ = spontaneous healing; $\mathrm{M}$ = porcine-derived collagen membrane alone; $\mathrm{GM}=$ porcine-derived graft material associated with collagen membrane.

Several studies [35-37] reported that following tooth extraction, the socket bone walls show reduced heights and widths, with dimensional changes more pronounced on the vestibular side. Results of the present study showed that using ESP techniques allow for better outcomes compared to tooth extraction alone. Both ESP procedures helped counteract bone resorption and remodelling of the socket walls, but neither technique could entirely compensate for the alveolar ridge reduction, especially in the vestibular aspect. Different flap designs have been proposed for ESP techniques in attempt to achieve soft tissue primary closure and to improve barrier adaptation. Vittorini Orgeas et al. [21] indicated that ESP techniques are effective regardless of whether primary flap closure is achieved. Data reported [38] exclusively for flapless approaches showed less bone changes compared to data reported for both flapless and non-flapless approaches. It could be speculated that the influence of flap elevation on wound healing of both soft and hard tissues would at least slightly modify the clinical outcome. Results of the present study showed that the flapless approach associated with secondary soft tissue closure and membrane exposure did not affect the efficacy of ESP technique associated with the use of collagen membrane alone or in combination with graft material. Outcomes of ESP techniques could be linked to physical and chemical features of the collagen membrane used. The collagen membrane used in the present study (Mem-Lok Pliabe $^{\circledR}$ ) has been previously compared in vitro [39] to a conventional collagen membrane (Bio-Gide ${ }^{\circledR}$ ).
The in vitro analysis showed that Mem-Lok Pliable ${ }^{\circledR}$ presents an initial rate of resorption slower than BioGide $^{\circledR}$ (12/14 weeks), and suggested that Mem-Lok Pliable $^{\circledR}$ is more stable than Bio-Gide ${ }^{\circledR}$ at the intraoral implantation site. In addition, the same study showed that Mem-Lok Pliable ${ }^{\circledR}$ collagen membrane elicits lower inflammatory and foreign body giant cell response than Bio-Gide ${ }^{\circledR}$. The chemical treatments of Mem-Lok Pliable ${ }^{\circledR}$ reduces the extent of inflammation and foreign body reactions to a higher degree than Bio-Gide ${ }^{\circledR}$. In conclusion, authors suggested that the lower degree of inflammation and foreign body response of Mem-Lok Pliable ${ }^{\circledR}$ may result in enhanced tissue integration and improved wound healing in terms of minimizing scar-like tissue formation. In the present study, premolar sites, extraction sockets type 1 , and extraction sockets with VBT $\geq 1.5 \mathrm{~mm}$ treated with collagen membrane alone, showed similar outcomes compared to those treated with porcinederived bone covered by collagen membrane. Based on these results, it is possible to hypothesize that in presence of extraction sites with a good volumetric bone support, the Mem-Lok Pliable ${ }^{\circledR}$ collagen membrane alone allows for limited bone remodelling and reabsorption processes. On the contrary, sockets with poor volumetric bone support (molar sites, extraction socket type 3 , and $\mathrm{VBT}<1.5 \mathrm{~mm}$ ) show better outcomes in ESP when Mem-Lok Pliable ${ }^{\circledR}$ collagen membrane is combined with porcine-derived bone. We realize that the sample size of the present study is too small to demonstrate whether premolar sites, extraction sockets type 1, and extraction 
sockets with VBT $\geq 1.5 \mathrm{~mm}$, might represent the indications to perform an ESP technique with collagen membrane alone. However, our outcomes confirm the hypothesis suggested by previous studies [3943] indicating that the tooth location, the type of extraction socket, and the thickness of vestibular bone plate represent predictive factors of remodelling after ESP procedures. The limitations of the present study include the small sample size and the short followup period. However, clinically relevant conclusions can still be drawn from the study and the results may serve as a basis for future analyses.

\section{CONCLUSIONS}

At the re-entry surgery, extraction sockets grafted with porcine-derived bone and covered by collagen membrane, and extraction sockets covered by porcine-derived collagen membrane alone, showed significantly lower vertical and horizontal bone changes, compared to extraction sockets sites underwent natural spontaneous healing. However, a complete prevention of remodelling is not achievable, irrespective of the technique used.

In the case of premolar sites, extraction sockets type 1 , and vestibular bone thickness $\geq 1.5 \mathrm{~mm}$, the use of collagen membrane alone showed similar results to the use of collagen membrane combined with bone graft.

\section{ACKNOWLEDGMENTS AND DISCLOSURE STATEMENTS}

The authors report no conflicts of interest related to this study. The study was performed with a grant of BioHorizons, Birmingham, AL, USA, that provided the materials.

\section{REFERENCES}

1. Claflin RS. Healing of disturbed and undisturbed extraction wounds. J Am Dent Assoc. 1936 Jun;23(6): 945-59. [doi: 10.14219/jada.archive.1936.0127]

2. Mangos JR. The Healing of Extraction Wounds: An Experimental Study Based on Microscopic and Radiographic Investigations. N Z Dent J. 1941; 37: 4-23.

3. Christopher ER. A histological study of bone healing in relation to the extraction of teeth. Northwest Univ Bul. 1942;43: 5-11.

4. Amler MH. The time sequence of tissue regeneration in human extraction wounds. Oral Surg Oral Med Oral Pathol. 1969 Mar;27(3):309-18. [Medline: 5251474] [doi: 10.1016/0030-4220(69)90357-0]

5. Amler MH, Johnson PL, Salman I. Histological and histochemical investigation of human alveolar socket healing in undisturbed extraction wounds. J Am Dent Assoc. 1960 Jul;61:32-44. [Medline: 13793201] [doi: 10.14219/jada.archive.1960.0152]

6. Boyne PJ. Osseous repair of the postextraction alveolus in man. Oral Surg Oral Med Oral Pathol. 1966 Jun;21(6):805-13. [Medline: 5219671] [doi: 10.1016/0030-4220(66)90104-6]

7. Trombelli L, Farina R, Marzola A, Bozzi L, Liljenberg B, Lindhe J. Modeling and remodeling of human extraction sockets. J Clin Periodontol. 2008 Jul;35(7):630-9. [Medline: 18498382] [doi: 10.1111/j.1600-051X.2008.01246.x]

8. Van der Weijden F, Dell'Acqua F, Slot DE. Alveolar bone dimensional changes of post-extraction sockets in humans: a systematic review. J Clin Periodontol. 2009 Dec;36(12):1048-58. [Medline: 19929956] [doi: 10.1111/j.1600-051X.2009.01482.x]

9. Johnson K. A study of the dimensional changes occurring in the maxilla following tooth extraction. Aust Dent J. 1969

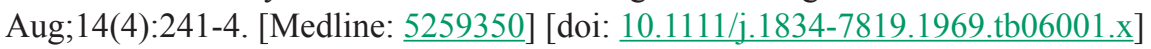

10. Atieh MA, Alsabeeha NH, Payne AG, Duncan W, Faggion CM, Esposito M. Interventions for replacing missing teeth: alveolar ridge preservation techniques for dental implant site development. Cochrane Database Syst Rev. 2015 May 28;(5):CD010176. [Medline: 26020735] [doi: 10.1002/14651858.CD010176.pub2]

11. Iocca O, Farcomeni A, Pardiñas Lopez S, Talib HS. Alveolar ridge preservation after tooth extraction: a Bayesian Network meta-analysis of grafting materials efficacy on prevention of bone height and width reduction. J Clin Periodontol. 2017 Jan;44(1):104-114. [Medline: 27712001] [doi: 10.1111/jcpe.12633]

12. Mardas N, Trullenque-Eriksson A, MacBeth N, Petrie A, Donos N. Does ridge preservation following tooth extraction improve implant treatment outcomes: a systematic review: Group 4: Therapeutic concepts \& methods. Clin Oral Implants Res. 2015 Sep;26 Suppl 11:180-201. [Medline: 26078004] [doi: 10.1111/clr.12639]

13. Jamjoom A, Cohen RE. Grafts for Ridge Preservation. J Funct Biomater. 2015 Aug 7;6(3):833-48. [Medline: 26262646] [PMC free article: 4598680] [doi: 10.3390/jfb6030833]

14. Masaki C, Nakamoto T, Mukaibo T, Kondo Y, Hosokawa R. Strategies for alveolar ridge reconstruction and preservation for implant therapy. J Prosthodont Res. 2015 Oct;59(4):220-8. [Medline: 26022542] [doi: 10.1016/j.jpor.2015.04.005] 
15. De Risi V, Clementini M, Vittorini G, Mannocci A, De Sanctis M. Alveolar ridge preservation techniques: a systematic review and meta-analysis of histological and histomorphometrical data. Clin Oral Implants Res. 2015 Jan;26(1):50-68. [Medline: 27007188] [doi: 10.1111/clr.12288]

16. Retzepi M, Donos N. Guided Bone Regeneration: biological principle and therapeutic applications. Clin Oral Implants Res. 2010 Jun;21(6):567-76. [Medline: 20666785] [doi: 10.1111/j.1600-0501.2010.01922.x]

17. Barone A, Aldini NN, Fini M, Giardino R, Calvo Guirado JL, Covani U. Xenograft versus extraction alone for ridge preservation after tooth removal: a clinical and histomorphometric study. J Periodontol. 2008 Aug;79(8):1370-7. [Medline: 18672985] [doi: 10.1902/jop.2008.070628]

18. Iasella JM, Greenwell H, Miller RL, Hill M, Drisko C, Bohra AA, Scheetz JP. Ridge preservation with freeze-dried bone allograft and a collagen membrane compared to extraction alone for implant site development: a clinical and histologic study in humans. J Periodontol. 2003 Jul;74(7):990-9. [Medline: 12931761] [doi: 10.1902/jop.2003.74.7.990]

19. Lekovic V, Kenney EB, Weinlaender M, Han T, Klokkevold P, Nedic M, Orsini M. A bone regenerative approach to alveolar ridge maintenance following tooth extraction. Report of 10 cases. J Periodontol. 1997 Jun;68(6):563-70. [Medline: $\underline{9203100]}$ [doi: 10.1902/jop.1997.68.6.563]

20. Lekovic V, Camargo PM, Klokkevold PR, Weinlaender M, Kenney EB, Dimitrijevic B, Nedic M. Preservation of alveolar bone in extraction sockets using bioabsorbable membranes. J Periodontol. 1998 Sep;69(9):1044-9. [Medline: 9776033] [doi: 10.1902/jop.1998.69.9.1044]

21. Vittorini Orgeas G, Clementini M, De Risi V, de Sanctis M. Surgical techniques for alveolar socket preservation: a systematic review. Int J Oral Maxillofac Implants. 2013 Jul-Aug;28(4):1049-61. [Medline: 23869363] [doi: $10.11607 /$ jomi.2670]

22. de Misquita MR, Bentini R, Goncalves F. The performance of bone tissue engineering scaffolds in in vivo animal models: A systematic review. J Biomater Appl. 2016 Nov;31(5):625-636. [Medline: 27334129] [doi: 10.1177/0885328216656476]

23. Becker W, Becker BE, Caffesse R. A comparison of demineralized freeze-dried bone and autologous bone to induce bone formation in human extraction sockets. J Periodontol. 1994 Dec;65(12):1128-33. [Medline: 7877084] [doi: 10.1902/jop.1994.65.12.1128]

24. Becker W, Urist M, Becker BE, Jackson W, Parry DA, Bartold M, Vincenzzi G, De Georges D, Niederwanger M. Clinical and histologic observations of sites implanted with intraoral autologous bone grafts or allografts. 15 human case reports. J Periodontol. 1996 Oct;67(10):1025-33. [Medline: 8910843] [doi: 10.1902/jop.1996.67.10.1025]

25. Froum S, Cho SC, Rosenberg E, Rohrer M, Tarnow D. Histological comparison of healing extraction sockets implanted with bioactive glass or demineralized freeze-dried bone allograft: a pilot study. J Periodontol. 2002 Jan;73(1):94-102. [Medline: 11846205] [doi: 10.1902/jop.2002.73.1.94]

26. Artzi Z, Tal H, Dayan D. Porous bovine bone mineral in healing of human extraction sockets. Part 1: histomorphometric evaluations at 9 months. J Periodontol. 2000 Jun;71(6):1015-23. [Medline: 10914806] [doi: 10.1902/jop.2000.71.6.1015]

27. Serino G, Biancu S, Iezzi G, Piattelli A. Ridge preservation following tooth extraction using a polylactide and polyglycolide sponge as space filler: a clinical and histological study in humans. Clin Oral Implants Res. 2003 Oct;14(5):651-8. [Medline: 12969370] [doi: 10.1034/j.1600-0501.2003.00970.x]

28. Fiorellini JP, Howell TH, Cochran D, Malmquist J, Lilly LC, Spagnoli D, Toljanic J, Jones A, Nevins M. Randomized study evaluating recombinant human bone morphogenetic protein-2 for extraction socket augmentation. J Periodontol. 2005 Apr;76(4):605-13. [Medline: 15857102] [doi: 10.1902/jop.2005.76.4.605]

29. Nannmark U, Sennerby L. The bone tissue responses to prehydrated and collagenated cortico-cancellous porcine bone grafts: a study in rabbit maxillary defects. Clin Implant Dent Relat Res. 2008 Dec;10(4):264-70. [Medline: 18241216] [doi: 10.1111/j.1708-8208.2007.00080.x]

30. Pagliani L, Andersson P, Lanza M, Nappo A, Verrocchi D, Volpe S, Sennerby L. A collagenated porcine bone substitute for augmentation at Neoss implant sites: a prospective 1-year multicenter case series study with histology. Clin Implant Dent Relat Res. 2012 Oct;14(5):746-58. [Medline: 20977615] [doi: 10.1111/j.1708-8208.2010.00314.x]

31. Guarnieri R, DeVilliers P, Grande M, Stefanelli LV, Di Carlo S, Pompa G. Histologic evaluation of bone healing of adjacent alveolar sockets grafted with bovine- and porcine-derived bone: a comparative case report in humans. Regen Biomater, 2017 Mar 1;4(2):125-8. [doi: 10.1093/rb/rbx002]

32. Barone A, Ricci M, Tonelli P, Santini S, Covani U. Tissue changes of extraction sockets in humans: a comparison of spontaneous healing vs. ridge preservation with secondary soft tissue healing. Clin Oral Implants Res. 2013 Nov;24(11):1231-7. [Medline: 22784417] [doi: 10.1111/j.1600-0501.2012.02535.x]

33. Barone A, Toti P, Quaranta A, Alfonsi F, Cucchi A, Calvo-Guirado JL, Negri B, Di Felice R, Covani U. Volumetric analysis of remodelling pattern after ridge preservation comparing use of two types of xenografts. A multicentre randomized clinical trial. Clin Oral Implants Res. 2016 Nov;27(11):e105-e115. [Medline: 25727443] [doi: 10.1111/clr.12572]

34. Juodzbalys G, Sakavicius D, Wang HL. Classification of extraction sockets based upon soft and hard tissue components. J Periodontol. 2008 Mar;79(3):413-24. [Medline: 18315423] [doi: 10.1902/jop.2008.070397]

35. Schropp L, Wenzel A, Kostopoulos L, Karring T. Bone healing and soft tissue contour changes following singletooth extraction: a clinical and radiographic 12-month prospective study. Int J Periodontics Restorative Dent. 2003 Aug;23(4):313-23. [Medline: 12956475] 
36. Araújo MG, Lindhe J. Dimensional ridge alterations following tooth extraction. An experimental study in the dog. J Clin Periodontol. 2005 Feb;32(2):212-8. [Medline: 15691354] [doi: 10.1111/j.1600-051X.2005.00642.x]

37. Cardaropoli D, Cardaropoli G. Preservation of the postextraction alveolar ridge: a clinical and histologic study. Int J Periodontics Restorative Dent. 2008 Oct;28(5):469-77. [Medline: 18990998]

38. Jambhekar S, Kernen F, Bidra AS. Clinical and histologic outcomes of socket grafting after flapless tooth extraction: a systematic review of randomized controlled clinical trials. J Prosthet Dent. 2015 May;113(5):371-82. [Medline: 25749077] [doi: 10.1016/j.prosdent.2014.12.009]

39. Li ST, Yuen D, Martin D, Lee NS. A Comparative Study of a New Porcine Collagen Membrane to Bio-Gide ${ }^{\circledR}$. Science, Technology, Innovation. 2015 Feb;1-5. [URL: https://www.osseonews.com]

40. Cosyn J, Cleymaet R, De Bruyn H. Predictors of Alveolar Process Remodeling Following Ridge Preservation in HighRisk Patients. Clin Implant Dent Relat Res. 2016 Apr;18(2):226-33. [Medline: 25041378] [doi: 10.1111/cid.12249]

41. Barone A, Toti P, Quaranta A, Alfonsi F, Cucchi A, Negri B, Di Felice R, Marchionni S, Calvo-Guirado JL, Covani U, Nannmark U. Clinical and Histological changes after ridge preservation with two xenografts: preliminary results from a multicentre randomized controlled clinical trial. J Clin Periodontol. 2017 Feb;44(2):204-214. [Medline: 27883211] [doi: $10.1111 /$ jepe.12655]

42. Ferrus J, Cecchinato D, Pjetursson EB, Lang NP, Sanz M, Lindhe J. Factors influencing ridge alterations following immediate implant placement into extraction sockets. Clin Oral Implants Res. 2010 Jan;21(1):22-9. [Medline: 19912273] [doi: 10.1111/j.1600-0501.2009.01825.x]

43. Januário AL, Duarte WR, Barriviera M, Mesti JC, Araújo MG, Lindhe J. Dimension of the facial bone wall in the anterior maxilla: a cone-beam computed tomography study. Clin Oral Implants Res. 2011 Oct;22(10):1168-71. [Medline: 21320168] [doi: 10.1111/j.1600-0501.2010.02086.x]

\section{To cite this article:}

Guarnieri R, Stefanelli L, De Angelis F, Mencio F, Pompa G, Di Carlo S.

Extraction Socket Preservation Using Porcine-Derived Collagen Membrane Alone or Associated with Porcine-Derived Bone. Clinical Results of Randomized Controlled Study

J Oral Maxillofac Res 2017;8(3):e5

URL: http://www.ejomr.org/JOMR/archives/2017/3/e5/v8n3e5.pdf

doi: $10.5037 /$ jomr.2017.8305

Copyright $\odot$ Guarnieri R, Stefanelli L, De Angelis F, Mencio F, Pompa G, Di Carlo S. Published in the JOURNAL OF ORAL \& MAXILLOFACIAL RESEARCH (http://www.ejomr.org), 30 September 2017.

This is an open-access article, first published in the JOURNAL OF ORAL \& MAXILLOFACIAL RESEARCH, distributed under the terms of the Creative Commons Attribution-Noncommercial-No Derivative Works 3.0 Unported License, which permits unrestricted non-commercial use, distribution, and reproduction in any medium, provided the original work and is properly cited. The copyright, license information and link to the original publication on (http://www.ejomr.org) must be included. 